\title{
GAYA BELAJAR SISWA BAGI BURHANUDDIN ZARNUJI
}

\author{
Hilman Haroen \\ FAI UCY
}

\begin{abstract}
This paper explores the learning styles in classical Islamic education. The focus is on the learning process recommended by Burhanuddin Zarnuji in his famous work of Ta'tim Al-Muta'allim. Through literature research, it is known that the learning styles developed are still not as they are now expected to be. More established classifications and categorizations are still in need of further steps.
\end{abstract}

Keywords: Learning style, Islamic education, Ta'lìm Al-Muta'allim

abstrak: Tulisan ini mengeksplorasi lebih lanjut tentang gaya belajar dalam Pendidikan Islam. Fokusnya pada proses pembelajaran yang dianjurkan oleh Burhanuddin Zarnuji dalam karya Ta'tīm Al-Muta'allim. Melalui penelitian literature dikatahui bahwa gaya belajar yang dikembangkan masih memang masih belum seperti halnya perkembangannya sekarang. Pengklasifikasian dan kategorisasi yang lebih mapan masih perlu langkah lanjutan.

Kata kunci: gaya Belajar, pendidikan Islam, Ta'tīm Al-Muta'allim

\section{A. Pendahuluan}

Buku Pendidikan Islam paling monumental hingga dewasa ini masih ditempati Ta'tīm Al- Muta'allim. Hal itu bisa dijelaskan oleh Ahwani dalam Madjidi. Diantara buku yang masyhur di kalangan bangsa Arab ditulis oleh Burhanuddin Zarnuji. Kitab ini sudah pernah disalin pula ke dalam Bahasa Latin. Rahasia kemasyhuran kitab ini terletak pada judul dan isinya yang khusus mengenai pendidikan dan pengajaran. Karangan seperti ini sedikit sekali terdapat dalam masyarakat Islam di saat itu. ${ }^{1}$

Sampai sekarang masih banyak yang mengakajinya hingga para sarjana Eropa dan Amerika. Nata mendaftar sarjana tersebut. Diantaranya; Van Grunebaum dan Abel, Brockelmann, atau Nakosten. ${ }^{2}$

${ }^{1}$ Busyairi Madjidi, Konsep Kependidikan Para Filosof Muslim (Yogyakarta: Al Amin Press, n.d.), h.121.

2Abuddin Nata, Pemikiran Para Tokoh Pendidikan (Jakarta: Raja Grafindo Persada, 2000), h. 107. 
Hilman juga mengakui Zarnuji sebagai peletak dasar konsep Pendidikan Islam. Ia di akui telah memiliki serta melandaskan pandangannya pada sistem epistemologi yang kuat dan mapan. Kitabnya mengklasifikasikan faktor-faktor pendidikan, dari tujuan, niat, metode pendidikan, hingga masalah pengertian ilmu, sumber ilmu, bagaimana mendapatkan ilmu. 3

Untuk mendapatkan ilmu, seseorang harus belajar. Skinner, dalam bukunya menjelaskannya sebagai suatu proses adaptasi atau penyesuaian tingkah laku yang berlangsung secara progresif. 4 Proses itu menjadi usaha yang dilakukan seseorang untuk memperoleh suatu perubahan tingkah laku yang baru secara keseluruhan sebagai hasil pengalamannya sendiri dalam interaksi dengan lingkungannya. Itulah penjelasan dari Slameto. 5

Dalam Pendidikan Islam, Tohirin menemukan anjuran agar manusia menggunakan potensi-potensi atau organ psiko-psikis, seperti akal, indera penglihatan (mata), dan pendengaran (telinga) untuk melakukan kegiatan belajar. Sebagai alat belajar, akal merupakan potensi kejiwaan manusia berupa sistem psikis yang kompleks untuk menyerap, mengolah, menyimpan, dan memproduksi kembali itemitem informasi dan ilmu pengetahuan. Selanjutnya, mata dan telinga merupakan alat fisik yang berguna untuk menerima informasi visual dan informasi verbal. ${ }^{6}$

Salah satu potensi alamiah kejiwaan yang penting adalah gaya belajar. Samples mengartikannya kebiasaan yang mencerminkan cara memperlakukan pengalaman dan informasi yang kita peroleh.7 De Porter menonjolkannya sebagai kombinasi dari bagaimana seseorang menyerap,

3Hilman Haroen, "Epistemologi Idealistik Syekh Az-Zarnuji Telaah Naskah Taâlim Al Mutaâalim,” Profetika: Jurnal Studi Islam 15, no. 02 (2016): 160-174.

4 Charles E. Skinner, Educational Psychology (New York: Prentice-hall, 1958), h. 199.

5Slameto, Belajar Dan Faktor-Faktor Yang Mempengaruhinya (Jakarta: Rineka Cipta, 2005), h. 2

6 Tohirin, Psikologi Pembelajaran Pendidikan Agama Islam (Jakarta: Raja Grafindo Persada, 2006), h. 54.

7Bob Samples, Revolusi Belajar Untuk Anak: Panduan Belajar Sambil Bermain Untuk Membuka Pikiran Anak-Anak Anda, terj. Rahmani Astuti (Bandung: Kaifa, 2002), h. 146. 
dan kemudian mengatur serta mengolah informasi. ${ }^{8}$ Oleh karena itu Nasution menyebutnya cara yang konsisten yang dilakukan oleh seorang murid dalam menangkap stimulus atau informasi, cara mengingat, berfikir dan memecahkan soal. 9

Gaya belajar setiap individu memang berbeda. Tidak semua orang mengikuti cara yang sama. Masing-masing menunjukkan perbedaan, namun para peneliti dapat menggolong-golongkannya. Mulyono mengkaitkan secara erat antara gaya belajar dengan pribadi seseorang, yang dipengaruhi oleh pembawaan, pengalaman, pendidikan, dan riwayat perkembangannya. ${ }^{10}$

Pada karya Haji Khalifah yang berjudul Kasyf al-Zunūn 'An Ansāmi' al-Kitāb al-Funūn telah ditegaskan bahwa kitab Ta'līm Al Muta'alim merupakan satu-satunya karya Zarnuji yang masih ada sampai sekarang. ${ }^{11}$ Keistimewaan kitab ini, bertumpu pada materi yang dibahasnya. Dengan sekilas jika melihat dari segi judulnya, akan segera tahu bahwa kitab ini membahas segi-segi belajar mengajar dengan segenap pernik-pernik yang dikandung. Dari metode, tujuan, prinsip, strategi dan lain sebagainya hingga bahasan mengenai pendefinisian ilmu, yang secara keseluruhan bertumpu pada azas moral religius.

Karya Ta'tīm Muta'allim, dengan demikian, merupakan petunjuk praktis agar seseorang dapat belajar dengan caranya sendiri tanpa kehilangan pertimbangan terhadap lingkungan sekitarnya. Proses demikian diakui memberikan dampak belajar yang signifikan. Eksplorasi filosofis pemikirannya tentang gaya belajar ini menjadi penting bagi sinkronisasi pembelajaran Pendidikan Islam yang relevan dengan tahapan perkembangan anak. Kajian filosofis seperti ini bisa memberikan dampak

${ }^{8}$ Bobbi DePorter, Quantum Learning: Unleashing the Genius in You, (New York: Dell Publishing, 1992), h. 112.

9S. Nasution, Berbagai Pendekatan dalam Proses Belajar Mengajar, (Jakarta: Bumi Aksara, ), h. 94.

10 Mulyono, Strategi Pembelajaran, (Malang: UIN-Maliki Press, 2012), h. 226228.

${ }^{11}$ Affandi Muchtar., "Ta'lim al-Muta'alim Tariq al-Ta'allum," Jurnal Pendidikan Islam (Cirebon; LKPP, edisi Perdana Aqustus 1995), h.67. 
terhadap pengembangan epistimologi pendidikan Islam modern tidak tercerabut dari sumber asal. ${ }^{12}$

\section{A. Kehidupan Zarnuji, Sang Pengarang}

Nama lengkapnya adalah Burhanuddin Al-Islam az-Zarnuji13. Nama Zarnuji dinisbatkan dari asal kotanya Yaitu suatu negeri yang menurut Qarasyi berada di Turki. Sedang menurut Yaqut terletak di Turkistan, di seberang sungai Tigris. ${ }^{14}$

Pendapat lain menyatakan nama belakangnya bukan berasal dari nama kota, sebagaimana sebagaimana kebiasaan pada masa itu. Plessner menyebut Zarnuji adalah nama asli, yakni Burhan al-Din Al- Zarnuji ${ }^{15}$

Padahal sebagian besar, Menurut Van Grunebaum dan Abel, Zarnuji adalah seorang ulama yang hidup di Persia. Keduanya juga meyakininya adalah ahli fikih bermazhab Hanafiyah yang dikenal luas di wilayah Kurasan dan Transoxiana. Meski demikian, ada kemungkinan lain adalah ada wilayah atau tempat dimana ia mengembangkan ilmunya. Yaitu di daerah Marginani. Wilayah ini dijadikan menjadi salah satu kemungkinan, karena dinisbatkan pada pertimbangan ulama yang dianggap sebagai gurunya. Imam Burhan ad-Din al-Marginani. Tetapi yang jelas paling tidak data ini menguatkan pendapat para ulama yangselama ini beranggapan bahwa Zarnuji hidup dan berkembang di Persia $^{16}$

Pendapat kedua ini membuat asal dari Zarnuji justru tidak jelas. Wilayah goegrafis dimana ia dilahirkan menjadi kabur. Problem pelik lain menyangkut tentang masa kehidupan Zarnuji, banyak mengundang pendapat kontroversial.

12 Haroen, Telaah Epistmologis; lihat juga Hilman Haroen, "Kebenaran Pengetahuan, Antara Barat Dan Timur," Jurnal Ilmu-ilmu Islam Ulumuddin 4 (1), 36-47

13Abuddin Nata. Pemikiran Para Tokoh Pendidikan (Jakarta; Raja Grasindo Persada, 2000), h. 107

14 Muhammad Abdul Qadir Ahmad, Kitab Ta'limul Muta'alim Tariqat Muta'allum (Kairo; Maktab An-Nahdah Al-Misriyah, 1986) h. 10

${ }_{15}$ M. Pleesner, "al-Zarnuji" dalam The Encyclopedia of IslamVol IV (Leiden: .3. Drill, 1917-174), h. 1218

${ }^{16 \mathrm{M}}$. Slamet Yahya, Metode Pembelajaran Menurut Az-Zarnuji (Telaah terhadap Progresivism) Tesis (Yogyakarta: UII, 2000) 
Para peneliti ada yang berpendapat bahwa Zarnuji hidup pada akhir abad 6H. Saat itu terjadi kemunduran Daulah Abbasiyyah. Zaman ini biasanya disebut periode kedua Daulah tersebut. Masanya ada dikisaran tahun 182- $658 \mathrm{H}^{17}$

Pendapat lainnya mengatakan Zarnuji, hidup pada periode ke empat Daulah Abbasiyyah. Periode ini disebut-sebut sebagai masa pertumbuhan dan perkembangan ilmu pengetahuan dan pendidikan Islam. Karena masa itu merupakan zaman keemasan atau kejayaan peradaban Islam pada umumnya ${ }^{18}$.

Pendapat terakhir dianggap mendekati kebenaran. Karena beberapa pendapat yang diungkapkan Plessner, Van Grunebaum dan Abel, dalam penelitiannya menunjukkan bahwa Zarnuji, hidup pada antara abad ke 12 dan ke 13. Semuanya mendukung kelahiran di masa tersebut. Ahlwardt dalam katalog kepustakaan Berlin, nomor III juga menyatakan bahwa Zarnuji hidup sekitar tahun 640 H (1245 M). Ia merujuk kepada al-Kaffawi dalam kitab A'lam al-Akhyār min Fuqahā' Mazhab al-Nu'mān alMukhdar. Di situ Zarnuji termasuk kelompok generasi kedua belas ulama Mazhab Hanafiyah. ${ }^{19}$

Beberapa gurunya termasyhur di masanya. Zarnuji pernah belajar kepada al-Marghinani. Seorang ulama yang mengarang kitab Hidayah $f i$ Furū' al-Fiqh, wafat tahun 593H/ 1195M. guru lainnya adalah Imām Fakhr al-Islām al-Hasan bin Masyūr al-Marginani Kadikhan. seorang ulama fikih Hanafiyah lainnya yang wafat pada tahun $592 \mathrm{H} / 1196$ M20. Selain itu Zarnuji juga menyebut nama Imam Zahir al-Din al-Hasan alKașani, (wafat tahun 587H/ 1191 M) dan Imam Rukn al-Dīn Muhammad bin Abi Bakr Imam Khawarzadi, yang diperkirakan hidup sekitar tahun 491-576 H. ${ }^{21}$

\section{B. Gaya Belajar dalam Karangan}

17Busyairi Madjidi. Konsep Kependidikan Para Filosof Muslim (Yogyakarta; AlAmin Press, 1997), h. 101

18 Nata, Sejarah Pemikiran, h. 105.

19Abulal-A'la al-Maududi., al Khalifah wa al-Mulk (Bandung: Mizan. 1990), h. 285-303

2oIbid., h. 14

21 Ibid. 
Buku Ta'lim Muta'allim ditulis berdasar keprihatinan Zarnuji terhadap banyak penuntut ilmu yang gagal mencapai tujuannya. mereka tidak bisa memetik manfaat manis dari ilmu pengetahuan saat belajar. Penyebabnya, mereka itu tidak mengamalkan dan mensyiarkan ilmunya. Disamping itu, tentu dapat di kira-kira, para penuntut ilmu itu tidak memakai metode, kiat, strategi dan jurus-jurus yang tepat dalam menuntut ilmunya.

Untuk itulah, dalam kitab ini Zarnuji berusaha menjelaskan kepada para penuntut ilmu, perihal prinsip-prinsip dasar yang harus dilalui, yang diharapkan dapat menjadi kode etik bagi penuntut ilmu itu. Demikian tepatlah makna judul kitab yang tersusun dalam 13 pasal. ${ }^{22}$

1. Pengertian Ilmu dan fikih serta keutamaannya.

Di awal uraiannya, Zarnuji menekankan bahwa setiap muslim wajib menuntut ilmu. Namun ilmu yang diwajibkan bagi setiap muslim itu menurut Zarnuji, tidak untuk semua ilmu yang ada di muka bumi ini. Tetapi, setiap muslim hanya diwajibkan untuk menuntut ilmu Hal, yakni ilmu tauhid, fikih, hadits dan sebagainya. Ilmu-ilmu yang diperlukan untuk menunjang kualitas keberagamaan muslim ataupun umat. Demi kualitas keberagamaan pula, menjadi wajib pula setiap muslim mempelajari ilmu-ilmu fikih seperti ilmu shalat, puasa dan lain-lain, karena setiap muslim diwajibkan menjalankan ibadah, yang merupakan wasilah (perantara) bagi yang Hal. 23

Di dalamnya juga ada ilmu-ilmu wasilah yang bersifat keduniawian yang bermanfaat bagi umat Islam, baik bagi diri sendiri maupun masyarakat. Misalnya mempelajari ilmu-ilmu perdagangan, jika ia adalah seorang pedagang. ${ }^{24}$ Zarnuji pun mengajarkan kepada setiap muslim agar bersikap taktis dalam setiap pekerjaan yang digelutinya, yang berhubungan dengan masalah-masalah muamalah. Belajar ilmu-ilmu yang

${ }^{22}$ Lihat juga Haroen, "Epistemologi Idealistik Syekh Az-Zarnuji Telaah Naskah Taâlim Al Mutaâalim," h. 54-66

23Mulyono, Strategi Pembelajaran (Malang: UIN-Maliki Press, 2012), h. 3-4.

24Zarnūji, Ta’lìm Al-Muta'allim Wa Tāriq at-Ta'allum (Beirut: al-Maktab alIslāmi, 1981), h. 14. 
berkaitan dengan pekerjaan yang digelutinya, diharapkan mendatangkan hasil dan keuntungan sebagaimana yang diharapkan.

Selain itu wajib pula mempelajari ilmu-ilmu yang berkaitan dengan moral dan etika (akhlak) yang luhur. Hal itu wajib pula dipelajari agar kaum muslim selalu menghiasi diri dengan akhlak yang mulia.25 Sementara bagi Zarnuji, mempelajari ilmu yang manfaatnya hanya dalam waktu-waktu tertentu hukumnya farḍu kifāyah. Ia menyatakan mempelajari ilmu-ilmu yang diperlukan setiap saat, ibarat makan yang diperlukan setiap individu. Adapun ilmu yang diperlukan pada waktuwaktu tertentu, laksana obat yang diperlukan saat sakit. Sementara itu mempelajari ilmu yang akan membahayakan diri, keluarga masyarakat dan agama, hukumnya haram. ${ }^{26}$.

Selain itu, secara spesifik, ia juga memberikan pendefinisian tentang ilmu. Bagi Zarnuji, ilmu adalah suatu sifat yang (semakin) menjelaskan identitas dari pemiliknya. Sedangkan fikih adalah untuk mangetahui kelembutan dan keindahan macam-macam ilmu. Lebih lanjut, Zarnuji menekankan tujuan ilmu tidak lain dan tidak bukan hanya untuk diamalkan, dan mengamalkan ilmu berarti meninggalkan orientasi duniawi demi ukhrowi. ${ }^{27}$

2. Niat dan Waktu Belajar.

Niat sebagai dasar dan motivasi bagi seorang murid dalam mencari ilmu pengetahuan. Niat juga menjadi intisari pokok dari setiap hal. Ia mensitir hadits Nabi Muhammad SAW-- yang berbunyi: "Bahwasanya amal perbuatan itu terserah niatnya"-- sebagai dasarnya. Itulah sebabnya,ia menganjurkan setiap muslim untuk selalu berniat baik dalam setiap hal termasuk dalam menuntut ilmu.

Zarnuji menekankan kepada para murid untuk benar-benar menanamkan kuat-kuat niat ini dalam hatinya. semakin kuat niat seseorang, akan semakin giat pula kerja seseorang yang muaranya akan semakin besar pula sukses (hasil) yang diperolehnya.

\footnotetext{
25 Ibid., h. 7

26 Ibid., h. 7-8

27 Ibid., h. 9-10
} 
Sehubungan dengan bahasan niat ini, Zarnuji secara tidak sengaja mengarahkan tujuan menuntut ilmu hendaknya diniatkan atau ditujukan guna mencari ridha Allah SWT, kebahagian akherat, memerangi kebodohan diri sendiri dan segenap kaum bodoh. Mengembangkan agama dan melanggengkan Islam. Sebab kelanggengan Islam hanya akan terwujud jika dijaga dengan ilmu pengetahuan. ${ }^{28}$

Terlihat pada konteks ini tampak visi epistemologi Zarnuji, bahwa belajar merupakan tugas agama. Sedangkan niat akan tampak bentuk utama dari tujuan pendidikan yang diorientasikan Zarnuji. Di luar itu prinsip belajarnya, memakai azas manfaat (utility). Selain itu niat menuntut ilmu harus diniatkan atau ditujukan untuk memperoleh kebahagiaan hidup di masa depan. Baik di dunia maupun akherat, maka Zarnuji juga menekankan arti penting profesionalitas.

Niat atau tujuan yang ketiga adalah hendaknya pendidikan dan atau pembelajaran supaya dapat membangkitkan kembali kesadaran agama dan syiar Islam.Az- Zarnuji menyadari arti panting pendidikan dan ilmu pengetahuan sebagai pilar dan prasyarat mendirikan bangsa.

3. Memilih ilmu, guru, teman dan ketabahan dalam belajar.

Ilmu merupakan jalan bagi manusia untuk mendapatkan pencerahan dan kemuliaan, sekaligus keluar dari kebodohan dan ketertinggalan.Hal itu jika manusia mampu memilih danIlmu merupakan jalan bagi manusia untuk mendapatkan pencerahan dan kemuliaan, sekaligus keluar dari kebodohan dan ketertinggalan.Hal itu jika manusia mampu memilih dan mengoptimalkan ilmu yang dia miliki, ke arah tujuan hidup yang diorientasi dan hendak yang ditujunya.

Itulah sebabnya dalam pasal ini, dianjurkan bagi setiap orang untuk memilih ilmu yang dianggapnya paling tepat dan bermanfaat serta sanggup ia kuasai bagi dirinya. Namun karena tujuan hidup seseorang tidak hanya sebatas hidup di dunia, maka ilmu yang terbagus yang harus ia pilih adalah ilmu agama, sebagai ilmu yang dibutuhkan setiap orang di setiap saat dalam menyempurnakan dan merealisasikan tujuan hidupnya.

28 Ibid., h. 11 
Menurut Zarnuji, ilmu yang terlebihdahulu yang harus dipelajari adalah ilmu tauhid. Karena dengan mengetahui ilmu tersebut orang dapat mengenal Allah secara lebih baik dan dewasa, sehingga ibadah seseorang terhindar dari taklid 29

Di luar itu, dalam memilih ilmu, hendaknya memilih ilmu kuno. Atau ilmu-ilmu yang sudah baku dan bukan ilmu-ilmu yang baru lahir. Sayang anjuran untuk memilih ilmu yang sifatnya kuno ini, Zarnuji tidak mengedepankan alasan kongkritnya. Namun barangkali, alasannya dapat dikira-kira, dengan memilih ilmu kuno, seseorang akan dengan mudah mendapatkan guru, mencari buku-buku (kitab) yang menjadi rujukan, serta sudah terbukti manfaatnya bagi masyarakat. Namun dengan memilih ilmu yang kuno, resikonya, akan terjadi persaingan yang kompetitif, sehingga jika tidak benar-benar profesional, ia tidak akan dapat turut bersaing sacara sehat dan kompetitif pula. Berbeda dengan ilmu-ilmu yang baru lahir, meski ia akan banyak menemui hambatan dalam belajarnyas namun ketika ia berhasil, ia akan sangat berguna di masyarakat. Karena persaingannya masih sangat langka.

Selanjutnya, ketika seseorang telah menentukan ilmu yang hendak dipelajari, Zarnuji mensyaratkan untuk memilih gurunya.Dalam memilih guru ini, hendaknya memilih guru yang lebih alim, wară', lebih lapang dada, penyabar dan lebih tua usianya, disamping yang sudah berpengalaman.

Hal ini dimaksudkan agar dalam menuntut ilmu dapat lebih terarah dan berkembang, sehingga dibutuhkan seorang guruyang dapat membimbing murid secara baik dan terarah. Karena menuntut ilmu merupakan urusan yang paling mulia sekaligus juga paling sulit, maka Zarnuji memerintahkan untuk.bermusyawarah dalam menuntut ilmu. Hal ini sebagaimana perintah Allah kepada Rasulullah, untuk selalu bermusyawarah dalam segala bidang kehidupan. Walaupun tidak ada orang lain yang lebih pintar dari pada Rasulullah sendiri3o

29Ibid., h. 15 .

30 Ibid., h. 16-18 
Selain itu dalam menuntut ilmu hendaknya selalu tabah dan sabar. Sementara dalam memilih teman dalam rangka mempelajari ilmu, hendaklah memilih teman yang tekun, wara', bertabiat, jujur serta mudah memahami masalah. Dan harus pula diusahakan untuk menyingkiri orang yang pemalas, penganggur, banyak bicara, suka mengacau dan gemar memfitnah. Memilih teman yang tepat, akan lebih bergairah dalam belajarnya, dengan demikian tujuan yang hendak dicapai akan mudah direalisasikan.

4. Perihal Mengagungkan Ilmu dan Ahli Ilmu

Dimana setelah menentukan pilihan akan ilmu yang dipelajari, memilih guru dan teman yang sesuai, berarti proses belajar sudah berlangsung, selanjutnya tugas murid supaya memperoleh kesuksesan dan manfaat dari ilmunya, seorang wajib mengagungkan ilmu, ahli ilmu dan menghormati gurunya.

Penjelasan pasal-pasal mengenai menghormati guru ini, pendapat Zarnuji jika dibandingkan sistem pendidikan modern terkesan berlebihan. Ia mencontohkan perilaku yang seharusnya dilakukan terhadap gurunya seperti, jangan berjalan di depan guru, duduk di dekat guru dan lain sebagainya. Hal ini dimaksudkan agar guru rela dalam mengajarkan ilmunya, menjauhkan amarah.

Guru dalam sistem pendidikan Islam, sebagaimana yang dilaksanakan pada sistem pendidikan pesantren, memang menjadi sentral seluruh aktifitas bagi proses belajar mengajar. Bahkan saking sentralnya, posisi guru menjadi sedemikian tinggi, terhormat dan prestisius, sehingga seluruh perintah dan larangan guru harus ditaatinya tanpa pandang bulu.Bahkan oleh anak raja (sultan sekalipun). Karena perintah dan larangan guru tak ubahnya hukum agama. Menjalankan perintah guru tak ubahnya menjalankan perintah agama, demikiansebaliknya.Termasuk dalam rangka mengagungkan ilmu, harus pula memuliakan kitab, menulis kitabdengan sebagus mungkin, menghormati teman sepengajaran dan guru yang mengajarnya.

Hal ini Zarnuji menekankan kepada para penuntut ilmu untuk senantiasa memperhatikan dan mengamalkan hal-hal tersebut di atas 
dengan disertai sikap tanggung jawab dan hormat. Zarnuji juga melarang untuk memilih ilmu sendiri. Masalah pilihan ilmu yang hendak dipelajari-karena posisi guru yang sedemikian sentral tersebut-- diserahkan kepada guru untuk memilihkan ilmu bagi muridnya.

Guru selalu jelas dan telah berkali-kali melakukan percobaan. Guru pula yang mengetahui ilmu apa yang sebaiknya diajarkan kepada seorang murid sesuai dengan watak, tabiat serta kebutuhan muridnya.Selain itu dalam belajar jangan terlalu dekat dengan guru, karena akan terkesan terlalu mengagung-agungkan gurunya. Di luar itu dalam pasal ini Zarnuji juga menganjurkan agar menyingkiri akhlak yang tercela ${ }^{31}$

5. Kesungguhan dan Kontinuitas Belajar serta cita-cita luhur

Pasal ini supaya murid sukses menempuh ilmunya, maka belajarnya harus dengan bersungguh-sungguh hati serta menempuhnya dengan kontinu (terus menerus). Hal ituharus dilakukan dengan mengulangulang pelajaranyang diterimanya. Waktu paling baik mengulangi pelajaran adalah awal waktu malam dan akhir waktu malam. Sebab waktu antara magrib dan isya' serta waktu sahur puasa menurutnya akanmembawa berkah.Selain itu, meski dalam menuntut ilmunya harus bersungguhsungguh, tapi jangan sampai kepayahan.Sehingga menjadi lemah dan tidak bisa mengerjakan pekerjaan lainnya.

Adapun sebagai penguat akanpernyataannya ini, Zarnuji menukil hadits Rasulullah yang artinya berbunyi: "Ingatlah bahwa agama ini (Islam) adalah agama yang kokoh, santunilah dirimu dalam menunaikan tugas agama. Janganlah kau buat dirimu sengsara lantaran ibadahmu kepada Allah. Sesungguhnya orang yang telah hilang kekuatannya tidak akan bisa meneruskan perjalanannya dan menunggangi kendaraan". Lebih lanjut Rasululaah bersabda; "Ilmu adalah kendaraan, maka santunilah ia"

Pada pasal ini Zarnuji juga menjelaskan setiap pelajar harus memiliki cita-cita yang luhur. Sebab cita-cita luhur disertai usaha sungguh-sungguh dengan cara menghayati keutamaan ilmu akan berhasil mendapatkan ilmunya.

${ }^{31}$ Ibid,. h. 25-30 
Selanjutnya Zarnuji menjelaskan tentang penyebab kemalasan. Menurut Zarnuji, yang menyebabkan kemalasan adalah lendir dan dahak. Juga badan yang terlalu berlemak karena kebanyakan makan, sehingga dalam pasal ini, Az.- Zarnuji memberikan resep dalam -mengurangi makanan. Yaitu dengan cara menghayati faedah dan manfaat makanan serta menghayati madharat dari akibat terlalu banyak makan ${ }^{32}$.

6. Permulaan Belajar, Ukuran Belajar Dan Tertibnya

Permulaan belajar yang baik, menurut Zarnuji adalah hari Rabu. Ini didasarkan dari riwayat sebuah hadits Rasulullah yang menyatakaan bahwa: "Tiada lain segala sesuatu yang dimulai pada hari rabu, kecuali akan sempurna".

Mengenai ukuran seberapa banyak pelajaran yang dikaji, Zarnuji mengambil pendapat dari Abu Hanifah yang disitir dari Qadi Imam Umar bin Abi Bakr Zinjiy. Dimana bagi orang yang baru memulai belajar, seharusnya mengambil pelajaran baru, sepanjang yang sekiranya mampu dihafalkan dengan faham, setelah diajarkan dua kali secara berulang. Kemudian untuk setiap harinya ditambat sedikit demi sedikit. Sehingga setelah banyak dan panjangpun masih tetap mampu menghapalnya dengan faham.

Mengenai masalah hafalan ini, dalam pasal ini Zarnuji memberikan resep metode menghafal, yakni dengan cara mengulang pelajaran yang kemarin sebanyak 5 kali, seterusnya hari lusa 4 kali, hari kemarin lusa 3 kali, dansebelumnyaa lagi 2 kali dan hari sebelum sebelumnya lagi 1 kali.

Sedangkan tertib belajar yang diajarkan Zarnuji meliputi; pertama tingkat pelajaran yang didahulukan, yaitu pelajaran yang mudah difahami; Kedua membuat catatan, yakni pelajar harus membuat catatan-catatan sendiri mengenai pelajaraan yang telah difahami dan dihafalkannya. Ketiga selalu berusaha memahami pelajaran; Keempat, berdoa dengan sungguh-sungguh; Kelima, mengadakan forum saling mengingatkan (muzakarah) dan forum saling mengadu pandangan (mutanadarah) serta

32 Ibid,. h. 31-44 
forum diskusi (mutharahah); Keenam dengan menggali ilmu dengan cara mengangan-angan dan memikirkannya hingga sedalam mungkin.

Pada pasal ini Zarnuji menyarankan agar pelajar selalu membiayai ilmunya. Tidak saja dengan materi (uang).Juga dengan selalu bersyukur, setiap kali berhasil memahami ilmu dan hikmah, dengan cara tersebut akan membuat ilmunya kian berkembang 33

7. Tawakal

Dimana Zarnuji menekankan agar selama menuntut ilmu agar selalu bertawakal kepada Allah.Dan agar jangan sampai goncang niatnya hanya karena masalah rejeki. Sebab hal itu akan membawa pengaruh buruk dalam mencapai budi luhur. Karena perhatiannya akan terpecah pada urusan dunia, akan lebih baik jika memperhatikan masalah masalah akherat. Sebab hanya masalah ini yang akan membawa manfaat.Selain itu, dalam menuntut ilmu, pasti akan banyak menemui rintangan dan kesusahan. Namun ia menganjurkan agar selalu bisa menghadapi hidup susah. Siapa yang dapat bertahan dalam menghadapi kesusahan, kesulitan dan rintangan, maka ia akan mendapatkan kelezatan dunia ${ }^{34}$

\section{Masa Belajar}

Masa belajar itu sejak manusia berada di buaian hingga masuk ke liang kubur". Selain itu ia juga menyatakan masa belajar yang paling cemerlangadalah permulaan masa-masa menjadi pemuda.Karena masa belajar yang demikian panjang itu, jika seorang murid hanya belajar satu bidang studi saja tentu akan mudah mengalami kebosanan. Untuk itu, Zarnuji menyatakanapabila sudah bosanmempelajari suatu hal, boleh berganti ke pelajaran lain35.

9. Kasih Sayang Dan Nasehat

Kedua sifat itu hendaknya menjadi sikap bagi seorang alim atau orang yang berilmu selain tidak berbuat dengki. Sebab sifat terakhir akan membahayakan diri sendiri. Dalam Pasal ini ada kiat-kiat bagaimana menghadapi kedengkian dan permusuhan. Yaitu dengan cara menghindari

33 Ibid., h. 44

34 Ibid., h. $45-60$

35 Ibid., 
turut melibatkan diri dalam arena pertikaian dan pertentangan pendapat dengan orang lain. Karena hal itu menurutnya hanya menghabiskan waktu dengan sia-sia. Yang kedua dengan menghindari berburuk sangka kepada sesama orang mukmin, karena itu merupakan sumber permusuhan 36 10. Menjelaskan cara "Mengambil Pelajaran"

Dalam pasal ini tertuang anjuran untuk selalu menggunakan setiap waktu dan kesempatan untuk belajar terus menerus sampai memperoleh keutamaan. Caranya selalu mencatat hal-hal ilmiah yang ia temui. Sebuah pepatah menyatakan: "Hafalan akan lari, tetapi tulisan tetap berdiri sendiri”

Hendaknya pula harus selalu mengambil pelajaran dari para sesepuh dan mencecap ilmu mereka di dalam kesempatan apapun, hal ini Zarnuji sangat menghormati dan memelihara keagungan ilmu dan keutamaan (ilmu) yang dimiliki oleh orang tua. Sehingga. karena suatu hal, ia sempat melewatkan waktunya untuk tidak melakukan hal itu, ia menjadi sangat kecewa. Pada sebuah syair ia menyatakan: "Sayang seribu sayang aku terlambat dan tak mendapat apapun yang Fana dan terlewat, tak mesti mendapat?"37

11. menjelaskan tentang "Wara' Dalam Masa Belajar"

Mengenai masalah wara' ini Zarnuji menyandarkan pada sebuah hadits Rasulullah SAW yang menyatakan sebagai berikut:"Barang siapa tidak berbuat wara' masa belajarnya, maka Allah memberi ujian dengan salah satu dari tiga perkara, dimatikan ketika masih berusia muda, ditempatkan pada perkampungan orang-orang bodoh atau dijadikan pengabdi sang pejabat"

Selain itu Zarnuji juga menyebutkan beberapa hal yang termasuk perbuatan wara'. Yakni memelihara diri sendiri jangan sampai kekenyangan, jangan terlalu banyak tidur dan terlalu banyak membicarakan hal-hal yang tak bermanfaat, menyingkiri makanan yang masak dari pasar:Karena makanan tersebut mudah terkena kotoran dan 
najis serta jauh dari dzikrillah. Selain itu harus menyingkiri kaum perusak, maksiat dan penganggur.

Dalam masa belajar, hendaklah selalu menjaga status dan kesopanan serta amal-amal sunnah. Sebab siapa yang mengabaikan adab, akan tertutup dari yang sunnah. Yang mengabaikan sunnah tertutup dari fardu dan berarti tertutup dari kebahagian akherat. Adapun salah satu yang dihukumi sunnah adalah belajar menghadap kiblat38.

12. Hal-Hal yang Membuat Mudah Hafal dan Lupa

Yaitu yang membuat mudah hafal yaitu kesungguhan, kontinuitas, mengurangi makan, memperbanyak shalat malamdan membaca $\mathrm{Al}$ Qur'an. Selain itu, penguat hafalan lainnya adalah sebelum belajar berdoa dengan mengucapkan basmallah dan mengakhiri dengan hamdalah. Juga banyak membaca shalawat nabi.

Sedangkan unsur-unsur penguat hafalan yang berupa materi adalah bersiwak, minum madu, makan kinder bercampur gula dan menelan zahib merah sebanyak 21 butir setiap hari. Hal itu dimaksudkan untuk mengurangi pelendiran dahak dan mengurangi pelemakan badan yang diakibatkan terlalu banyak makan.

Sedangkan hal-hal yang menyebabkan lupa adalah perbuatan maksiat, banyak dosa, gila, gelisah karena urusan dunia, juga karena terlalu sibuk mengurus dunia. Sementara itu penyebab lupa yang berbentuk materi adalah makan ketumbar, buah apel masam, melihat salib, membaca tulisan di atas kuburan, berjalan di sela-sela unta terkait, membuang ke tanah suatu yang masih hidup dan berbekam pada palung tengkuk kepala39.

13. Faktor-faktor lain

Dalam mempertahankan masa belajar, demikian menurut Zarnuji dibutuhkan faktor-faktor lain yang sifatnya mendukung seperti banyak rejeki dan panjang usia. Pasal ini mengingat lembaga pendidikan masa Zarnuji bersifat tradisional dalam bentuk Paguron Pesantren dimana selain murid harus belajar, ia juga harus mencukupi kebutuhan hidup 
sehari-harinya Zarnuji menjelaskan hal-hal yang dapat mendatangkan rejeki, seperti salat dengan takdim dan khusyu dengan menyempurnakan semua rukun, wajib dan sunnah serta adab kesopanannya.

Selain itu juga harus selalu berdoa di waktu terbit fajar hingga masuk waktu salat. Sementara yang menyebabkan rejeki seseorang tertutup adalah perbuatan dosa, banyak dusta, terlalu banyak tidur di pagi hari 40 dan lain-lain.

\section{Kesimpulan}

Zarnuji tulisannya tentang gaya belajar ini memang masih belum seperti halnya perkembangannya sekarang. Pengklasifikasian dan kategorisasi yang lebih mapan masih perlu langkah lanjutan. Ciri awal penulisannya dalam Ta'lim muta'allim memang berciri umum dari penulisan kitab-kitab tradisional yang bernafaskan Islam. Hal ini bisa difahami, disamping rasa rendah diri (tawadlu) dari penulisnya, sehingga wajib hormat pada yang pantas dihormati dan diagungkan.Juga karena, secara hirarkhis hal itu manunjukkan sumber-sumbar dan azas ilmu pengetahuan (yang) Islami.

Kitab Ta'lim al-Muta'allim adalah karya besar dan monumentaI Zarnuji ini disusun secara detail, sistematis dan praktis. Karya ini bukanlah kajian teoritis yang mendalam, namun mengarahkan pembacanya untuk menerapakan gaya belajar yang "seharusnya". Setidaknya dapat menjadi buku pegangan bagi penuntut ilmu yang hendak mendapatkan kesuksesan belajarnya dengan baik dan benar. Bahkan pembahasan khas dari buku ini telah memunculkan pasal mengenai rejeki. Dalam sistem pendidikan klasik hal ini jarang disentuh bahkan dipersoalkan, karena dianggap tidak berkaitan dengan masalah ilmu dan pendidikan. Sekarang tingkat kemakmuran dan pendapatan bisa menjadi salah satu indicator keberhasilan pendidikan.

\section{Daftar Pustaka}

Haroen, Hilman. "Epistemologi Idealistik Syekh Az-Zarnuji, Telaah Naskah Tā'lim al-Muta'allim.” Profetika: Jurnal Studi Islam 15, no. 02 (2016): 160-174.

Madjidi, Busyairi. Konsep Kependidikan Para Filosof Muslim. Yogyakarta:

${ }^{40}$ Ibid., h. 82-90 
Al Amin Press, n.d.

Mulyono. Strategi Pembelajaran. Malang: UIN-Maliki Press, 2012.

Nata, Abuddin. Pemikiran Para Tokoh Pendidikan. Jakarta: Raja Grafindo Persada, 2000.

Samples, Bob. Revolusi Belajar Untuk Anak: Panduan Belajar Sambil Bermain Untuk Membuka Pikiran Anak-Anak Anda. Terj. Rahmani Astuti. Bandung: Kaifa, 2002.

Skinner, Charles E. Educational Psychology. New York: Prentice-hall, 1958.

Slameto. Belajar Dan Faktor-Faktor Yang Mempengaruhinya. Jakarta: Rineka Cipta, 2005.

Tohirin. Psikologi Pembelajaran Pendidikan Agama Islam. Jakarta: Raja Grafindo Persada, 2006.

Zarnūji. Ta'līm Al-Muta'allim Wa Tāriq at-Ta'allum. Beirut: al-Maktab alIslāmi, 1981. 
Hilman Haroen 